\title{
DRAMATIC EFFECTS IN THE SHORT STORIES OF K. RAKHMANOV
}

\author{
Seytbekov Adilbay Batirbekovich \\ Independent Researcher, Nukus State Pedagogical Institute,
}

Article DOI: https://doi.org/10.36713/epra4229

\begin{abstract}
ANNOTATION
For Karakalpak literature XX-century was the century of close interaction with world literature. This process had a huge impact on the expansion of the genre diversity of Karakalpak literature. In literature appeared a great number of new genre kinds: drama, tragedy, comedy, story, novel, ballad, tale, poem and etc.

One of new genre varieties in Karakalpak literature is origin of mixed genre-forming. i.e Works, including in it features of lyrics and drama, lyrics and epos, comedy and tragedy, lyrics and prose and etc. and Karakalpak poets, writers became successfully in using new genres.

The signs of the drama in this or that measure can be presented in epos works, but signs of the epos are not alien to the drama. Their lyrics penetration is much more productive than lyrics penetration into these genres and inside out.

This is evidenced by the fact in the Karakalpak literature today there is often processing of the epic works in drama. But it should be recognized that there is little success, because any original work is unique, especially dramatic. Based on this concept, we tried to consider the problem of the synthesis of genres by the example of works by K.Rakhmanov where interpretation of tragedy, comedy, epic is evident.
\end{abstract}

KEY WORDS: genre; drama; epos; synthesis; tragicomedy; novel; plot; composition; conflict.

\section{DISCUSSION}

Kenesbay Rakhmanov is one of the wellknown Karakalpak playwrights and the author of many drama works. Perhaps, therefore, there are many elements of drama including dramatic effects in his prose. In the literary work, drama makes events tenser and connects the internal feelings of the characters with the outer environment arousing the readers' interest in the work.

In comparison with other genres the events in the dramatic work are more entangled and tenser, the spiritual life of the characters come under the influence of the outer world.

Therefore, the drama of the event and the character's spiritual drama come to the fore. Sometimes this phenomenon in the literary work is called dramatic effect" [1.67].

Some of the writer's prose works had been redone by him and later became popular as dramatic works. For example, on the basis of the short story "Noser" (Torrential Rain) he created the comedy
"Lakkhylar emleukhanada" (Comedians in Hospital). As we mentioned before, in the prose works of the writer, the dramatic elements, especially, the intertwining of events and the tension of the internal feelings of characters occur more often. This strengthens his epic works' eventfulness and the attractiveness of their conflicts.

Although the comedy is mainly based on the events that took place in the hospital in the story Torrential Rain, the idea of the play differs from the story. That is to say, in the comedy Comedians in Hospital, the playwright put forward high humanistic ideas by connecting fates of several characters. Especially, it is seen in the character of Atazhan from the story and in the character of Alpamys from the play. In the short story all events develop around Atazhan, whose gullibility and humbleness cause the dramatic episodes to increase. As for Alpamys, he is absolutely different hero. He is a personage who has chosen the wrong way since his childhood, furthermore, he is ill-bred, and prone to commit 
crime. In hospital, the patients who were in the same ward with him, try to educate and show him the right way.

However, their "pedagogical activity" did not bring any result. He escaped the ward after having beaten Dauen Zhilli. In this work the dramatic effects are conveyed through the image of Alpamys.

We also dwelt on the events in the hospital while describing the characters from the story Torrential Rain. K.Rakhmanov used this scene successfully and managed to create one more dramatically piece by developing the images of its characters. Using one scene from the story Torrential Rain as a basis, K. Rakhmanov reveals the images of each character not by describing them one by one, but according to the drama genre, by way of their words and level of their personal vocabulary.

Almost all the characters in the play are the ones from the story Torrential Rain. There is not any particular difference in their behaviors, speech and characters. However, the image of Atazhan, the main character of the story, is not represented in the play. Instead of him the image of Alpamys is introduced in the play. Although this image is used only as a secondary character, the playwright used it productively to entangle the events of the play and to gather the heroes for a certain goal.

In general, as most people agree, the play Comedians in Hospital is worth of its name, and one of the achievements of the comedy genre in Karakalpak dramaturgy. All the same, one can see that the events lack of wholeness to some degree, and the images are not revealed in full. In most cases there are descriptions peculiar to the genre of prose. In our opinion, it might have been due to the fact that it is based on the short story.

"If the writer creates a dramatic work on the basis of the plot, event, or material of a prose work, he cannot reach a creative success. Both in prose and poetry, the author can freely describe the activities of characters, their lives through his own thinking and feelings.

However, in dramaturgy writers do not have such an opportunity. In a play, the event, the conflict, characters, and the portrayal appear on the stage all together right before the eyes of the spectators. Even a tiny defect in one of them can harm all the details," said a literary critic A. Nasrullaev [2, 137-138].

It is true that such drawbacks can also be found in the creative works by K. Rakhmanov. In the work of drama, words, actions and portrayals are considered as unalienable parts completing each other. Actions and appearance define the fate of the hero. Therefore, this genre requires from the author a great concentration and experience. In its turn, the novel "Akhybet" (Consequence) served as the material for the tragicomedy "O Dunyuagha mirat" (The Invitation to the Other World).

The novel is about the events of the $80 \mathrm{~s}$ and is regarded as one of the most unique productions in our literature. The difference of the novel from the other books of the writer is that the events are not retold by the author or by one of the main characters, but by each of the images of the book. In other words, each image's features become known through their dialogues and monologues.

The author created truthful dialogues and monologues of each character of the novel Consequence in order to make each individual image look original. The language used in the novel is true to the life and close to spoken, everyday language rather than artificial, made up words. Such an achievement we can see not only in the words of the main characters mentioned above, but also in the language of the secondary, minor characters.

The image of Taspolat is a typical image of high - ranking officials of the so - called stagnation period in the society. Such disgraceful figures we can find in the image of Amirkhan in Sh. Seitov's novel "Zhaman Shangarakhtaghy Akhtuba" (Akhtuba in Zhaman Shangarakh), in the image of the director in A. Abdiev's novel "Zhin Zhypyrlar uyasy"( The Nest of Devils). In these books, the officials appointed by the government tend to mock at women. "The Invitation to the Other World" is a tragicomedy consisting of two parts, five scenes, a prologue and an epilogue. A few images such as Taspolat, Ulperi, Nurpolat, Sherniyaz, Aiparsha, Auez, Mamont, Shchuka, Matmuratov, and Dauranbekov are the heroes of the play. The same characters are the main characters of the novel Consequence.

If we pay attention to the way of creating the images of the characters in the play, we can see that their activities, behavior, and language do not differ much from those described in the novel. The author adapted some events of the plot of the novel to the stage and improved considerably the dialogues and monologues of the characters. As a result, this production is more interesting than the comedy Comedians in Hospital created on the basis of the short story Terrestrial Rain.

As the play The Invitation to the Other World is a tragicomedy, we see in the images of the characters the features peculiar to these two genres.

For instance, there are many comic moments in the first and second scenes of the first part of the play. Here, the dialogues among Taspolat, Ulperi and Sherniyaz are portrayed skillfully. As the events develop, the content of the play changes and the events get entangled in sad incidents. The main cause of this, of course, is the main idea of the production i.e., the regrettable results of bad habits such as 


\section{SJIF Impact Factor: 6.260| ISI I.F.Value:1.241| Journal DOI: 10.36713/epra2016 ISSN: 2455-7838(Online) EPRA International Journal of Research and Development (IJRD)}

obsession with flashy things, fraudulence, and amoral behavior and other vices.

Thus, we can consider the play The Invitation to the Other World one of the best productions in the Karakalpak dramaturgy in terms of content, ideological and thematic meaning and the skilful creation of images.

The novel "Tunghysh mukhabbat" (First Love) by $\mathrm{k}$. Rakhmanov was one of the largest creations in our national literature in the period of independence. The events in the book are depicted in direct connection with the main hero Shamurat. Because with the help of his monologues the author creates a complete image and portrays the images of other characters on the basis of Shamurat's views. In other words, the novel is told completely through Shamurat's narrations.

Famous Kazakh literary critic B. Wakhatov once wrote, "The real artistry can be shown by demonstrating man's spiritual state and behavior. However, that character and behavior should change and develop like a live organism" $[3,62]$.

Similarly, the image of Shamurat is the image which develops from the beginning to the end of the novel. If at the beginning of the novel we see the image of a simple adolescent, at the end of the book we can see a total turn in the image, absolute change in his conscience.

In the monologues of this image, which was created as the narrator of the events, his struggles in his life, the hardest moments, the new feelings born in his internal world are revealed. Describing the latest results of the most complex events experienced by the other characters, the author was able to convey each character's intended idea. Here, the skill of the author allowed him to unify his own words with that of the character, and depict what he could not convey in his own words with the help of the character's words.

In the novel under discussion, dialogues also play a certain part in revealing the mutual relations, features of characters, spiritual worlds of the heroes, and, in general, the content of the book. Along with it, each character becomes a whole image with its original way of speech.

For example, in the dialogues between Shamurat and his father, an old man Baimurat, along with their own relations the other characters are also discussed. In such cases, the communications between the characters develop their own images while disclosing the traits of the other characters.

Take for instance this dialogue, "Shamurat, stop beating about the bush," said my father calling me to order. - I have almost spoken to everybody. It goes without saying when our community leader Babakeng has given us his permission. No one can disobey him. I've also got the key. Now go and open the big padlock of the Aziyra's house. Gather your friends. Sweep and tidy up the rooms. No one has lived in that house ... God knows, maybe snakes are breeding there.

- Snakes!? Then I won't even go there. I'm very afraid of snakes, shrieked I.

Daddy smiled.

- If Aitmurat goes there, all snakes will run away. Maybe even a tiger gets scared of his appearance" $[4,19]$.

This is a dialogue between Shamurat and an old man Baimurat. In it not only the everyday problems are discussed but also the perseverance, egoism and hot temperedness peculiar to the image of Aitmurat.

As for the image of Nazlybiyke, we can see that she is a lot more patient than Aitmurat, always acts cautiously and never says anything without being sure of her words. She knows that Aimurat has left her forever, but, all the same, she stays with her mother-in-law and father-in-law, and continues to fulfill her duty as the daughter-in-law. She wants to live surrendering to her fate without paying any attention the gossips going around. Unfortunately, Nazlybiyke cannot afford to tolerate all the hardships of life. As a result, after the unpleasant incidents with her brother-in-law Shamurat, she also has to go far away.

Since the events in the novel take such a strange turn, Nazlybiyke's image might seem weak. However, she finds power in herself to change her fate for the better and to start a new life.

In general, the characters in the novel differ significantly from each other; in creating them the author tried his best so that the activities and words of one character would not be repeated by another. Although most images are of general humanistic character, their outlook and psychology are not like each other. In spite of the fact that the writer created some disgusting images causing hatred in the readers, he managed to show the difference in their characters.

People and personages of different type are depicted in the novel. Such a good many images serve to completely reveal the eventful period described in it. The novel's richness in events, images and versatility, gives it an epical character.

"In Epical work, one of the main tasks is portraying the masses, showing their character", said Academician M. Nurmukhametov [4, 144]. Exactly such descriptions of the masses can be found in the novel. Take for example, the wedding party of Baimurat's son Aitmurat, the scenes from the funeral of the oldest person of the community Babaniyaz.

It should be pointed out that in $\mathrm{K}$. Rakhmanov's prose works, the feeling of the spirit of the time, closeness to the real life are the main advantages. Such a characteristic peculiarity 
strengthens the realistic spirit of the events and images depicted in his stories and novels, and their connection with people's life.

"Here, in connection with this the personal features of each writer come to light. Therefore, it is impossible to conclude and say that one can write about such things and cannot write about other things... We have decided to assert in this chapter of our work that the main principle of the belles-lettres is to instill confidence in people by truthfully describing the social life or the circumstances. [5, 21].

Well then the object of research of the literary work is the life in general, nature and social events. However, in the center of the research is man, his life, actions, internal feelings, struggles, love and problems. Therefore, we can conclude that the main subject of the literary work is man.

The writer skillfully used various methods of creating external portraits, dialogues, internal monologues The writer used skillfully various, which had already been tried in the world literature, to describe his images completely and deeply in accordance with their characters. The use of these methods makes the heroes' characters more natural and lifelike.

\section{REFERENCES}

1. Akhmetov S., Esenov J.., Jarimbetov Kh. Karakalpak-Russian Explanatory Dictionary. Nukus: Bilim, 1994.

2. Nasrullaev A. The Dramaturgy of J. Aimurzaev. Nukus: Khkh-stan, 1977.

3. Wakhatov B. The Fruits of Talent. Almaty, 1962.

4. “Amiudarya” journal, 2004, issue 2.

5. Nurmukhametov M. Works. Vol.2. Nukus, 1985.

6. Sultanov Kh. T. The Prose Works of T. Khaipbergenov. Nukus, 1979. 